\begin{tabular}{|c|l|}
\hline Title & Effect of cathode separator structure on performance characteristics of free breathing PEMFCs \\
\hline Author(s) & Tabe, Y utaka; Park, Sang-Kyun; Kikuta, Kazushige; Chikahisa, Takemi; Hishinuma, Y ukio \\
\hline Citation & $\begin{array}{l}\text { Journal of Power Sources, 162(1), 58-65 } \\
\text { https://doi.org/10.1016/.jpowsour.2006.06.093 }\end{array}$ \\
\hline Issue Date & 2006-11-08 \\
\hline Doc URL & http://hdl.handle.net/2115/16894 \\
\hline Type & article (author version) \\
\hline File Information & JPS162-1.pdf \\
\hline
\end{tabular}

Instructions for use 


\title{
Effect of cathode separator structure on performance characteristics
}

\author{
of free-breathing PEMFCs \\ Yutaka TABE $^{1 *}$, Sang-kyun PARK ${ }^{1}$, Kazushige KIKUTA ${ }^{1}$, Takemi CHIKAHISA ${ }^{1}$ \\ and Yukio HISHINUMA ${ }^{2}$ \\ ${ }^{1}$ Division of Energy and Environmental Systems, Hokkaido University \\ N13 W8, Kita-ku, Sapporo 060-8628, JAPAN \\ ${ }^{2}$ E\&E Research Inc., Japan \\ 4-8-3, Nishinarusawa-cho, Hitachi 316-0032, JAPAN \\ * Corresponding author. Tel.: +81-11-706-6381; Fax: +81-11-706-7889. \\ E-mail address: tabe@eng.hokudai.ac.jp; N13 W8, Kita-ku, Sapporo 060-8628, JAPAN.
}

\begin{abstract}
The performance of free-breathing polymer electrolyte membrane fuel cells (PEMFCs) was studied experimentally and the effect of the cathode separator structure on the cell performance was investigated. Two types of cathode separators were used for a cell with an $18 \mathrm{~cm}^{2}$ active area: an open type with parallel rectangular open-slits and a channel type with straight vertical channels with open ends. The polarization curves, cell impedance, and contact pressure distribution of the separators were measured with each type of cathode structure. The result showed that it is difficult to realize a uniform contact pressure across the cell layers for the open type separator, and this results in higher contact resistance and poorer cell performance than the channel type separator. The channel type separator can maintain a low contact resistance, and the cell performance is strongly affected by the natural convection inside the channel. Optimization of the channel design of the channel type separator achieves good performance and this type of separator is superior for a free-breathing PEMFC. A computational three-dimensional analysis for the free-breathing channel type PEMFC with the different channel depths was performed, and it identified the influence of natural convection.
\end{abstract}

Keywords: $\quad$ PEMFC, Free-breathing, Open type, Channel type, Contact resistance, Power

\section{Introduction}

The polymer electrolyte membrane fuel cell (PEMFC) has attracted increasing attention as a portable power source for cellular phones, notebook computers, and applications in small robots because of its longer operation time compared with the conventional rechargeable battery and as there is no need to recharge $[1,2]$. To achieve practical use of the PEMFC, a further reduction in size and weight is needed and reducing auxiliary devices is desirable. The free-breathing PEMFC has been proposed as one kind of small size PEMFC systems. As oxygen from the air is fed by natural convection at the cathode side of the free-breathing PEMFC, there is no need of an auxiliary oxygen supply device.

Cathode separators of the free-breathing PEMFC may be classified into two types. An open type separator has open-slits where the ambient air is supplied directly thorough the slits, and a channel type separator has straight vertical channels with open ends where the ambient air is supplied from the bottom of the open ends and flows upward by buoyancy. 
A number of studies have been conducted on the free-breathing PEMFC with the open type separator and also with the channel type separator. For the open type cells, there are reports of the cell design [3,4], the effect of the slit structure of the separator on the cell performance [5], current distribution measurements, and the effects of the temperature and humidity of the surrounding air [6]. For the channel type cells, there have been investigations of the effect of the temperature and humidity of the surrounding air on the stack performance [7] and measurements of the current distribution [8]. These reports focus on the performance of one type of cell or stack with a specific structure, and there is very little data on the characteristics of the cathode separator structure comparing the performance of cells with similar active areas. Thus, the optimum structure of the cathode separator for a free-breathing PEMFC has not been fully investigated.

The aim of this study is to establish the effect of the cathode separator structure on the cell performance of a free-breathing PEMFC without compressor and humidifier. The cell performances of two cathode separator types were compared and the factors dominating the performance are discussed. The effects of the channel width and depth on the cell performance, which appears to be related to natural convection in the channels, were also examined experimentally in the channel type cells. Further, a three-dimensional numerical simulation was conducted on the natural convection inside the channel and the distribution of gas compositions to investigate the oxygen supply capability on the cathode side and to explain the results obtained in the experiments.

\section{Experimental apparatus and method}

An outline of the free-breathing PEMFC in this study is shown in Fig. 1. From the left, the cell is composed of an anode end-plate, anode separator, carbon paper, membrane electrode assembly (MEA), carbon paper, cathode separator, and cathode end-plate. The assembly pressure on the cells was $2.8 \mathrm{MPa}$. Both cells had active areas of $18 \mathrm{~cm}^{2}(40 \mathrm{~mm}(\mathrm{H}) \times 45 \mathrm{~mm}(\mathrm{~W}))$ and used same parts except for the cathode separator and end-plates. The anode side separator was gold-plated 304 stainless steel operated as a current collector and flow-field plate for hydrogen. The MEA was PRIMEA Series 5510 (Japan GORE-TEX Inc.), the gas diffusion layer (GDL) was carbon paper of TGP-H (Toray Industries, Inc.), and the GDL thicknesses were varied from 0.1 to $2.16 \mathrm{~mm}$ by adding $0.1 \mathrm{~mm}$ or $0.27 \mathrm{~mm}$ thick carbon papers. The GDL thickness at the anode side was constant, $0.54 \mathrm{~mm}$. The open type cathode separator made of $1 \mathrm{~mm}$ thick 304 stainless steel has opening slits of $2 \times 45 \mathrm{~mm}^{2}$ at $1 \mathrm{~mm}$ intervals. The separator was held together by the $10 \mathrm{~mm}$ thick end-plate with a $40 \mathrm{x} 45 \mathrm{~mm}^{2}$ window at the center. The channel type cathode separators were made of 5154 aluminum and designed with 1 and $2 \mathrm{~mm}$ wide channels. The channel depths were $2,4,6,8$, or $10 \mathrm{~mm}$ for the $2 \mathrm{~mm}$ wide channels and 2,5 or $10 \mathrm{~mm}$ for the $1 \mathrm{~mm}$ wide channels. All channel lengths were $60 \mathrm{~mm}$ and widths of current collecting rib were $1 \mathrm{~mm}$. No decline in cell performance due to surface corrosion of the stainless or the aluminum separators was observed during the experiments.

To simulate the condition without humidifier and heater, dry hydrogen of $99.999 \%$ purity was fed to the anode at atmospheric pressure from a pressurized bottle. The flow rate of the hydrogen was $0.3 \mathrm{~L} \mathrm{~min}^{-1}$ for a stoichiometry of 2.5 at $900 \mathrm{~mA} \mathrm{~cm}^{-2}$, and the influence of the anode side concentration overpotential on the cell performance can be disregarded. On the cathode side, ambient air was supplied by natural convection. The temperature of the ambient air during the polarization measurements was $18 \sim 22{ }^{\circ} \mathrm{C}$ and the relative humidity $21 \sim$ $33 \%$. The cell voltages were determined by average values measured over three minutes at each current density.

\section{Results and Discussion}

\subsection{Effect of cathode separator type}


A free-breathing PEMFC requires both a sufficient supply of oxygen to the cathode reaction layer and a uniform small electric resistance for the cell layers. These factors influence performance differently depending on the cathode structure: a wider channel width and thinner gas diffusion layer (GDL) cause a higher diffusivity of gases but a heterogeneous distribution of electric resistance. Wider channel widths decrease the contact area of the separator and the GDL, and a thinner GDL increases the electric resistance along the layer, reducing the electric current passing from the reaction area under the channel to the separator rib. This section reports experimental result to evaluate the effects of these factors on the cell performance with the different cathode separators.

Fig. 2 shows the polarization curves of the open and the channel cathode type cells with three different cathode GDL thicknesses, $0.1,0.54$, and $2.16 \mathrm{~mm}$. The channel of the channel type separator was $6 \mathrm{~mm}$ deep and $2 \mathrm{~mm}$ wide. The polarization curves show that both the open and channel type cell performances are strongly affected by the GDL thickness. The limiting current density, where voltage drops abruptly, decreases as the GDL thickness increases. This is explained by the increase in the concentration overpotential as the oxygen supply on the cathode side is inadequate, and the effect of the GDL thickness on the oxygen diffusion is considered to be an important factor in the free-breathing PEMFC performance. It was expected that the oxygen diffusion with the open type separator would be superior to that with the channel type separator because ambient air is supplied directly through the slits, but there is no significant differences in the limiting current density at the experimental conditions, as shown in Fig. 2. The cell voltages decrease linearly in the middle range of the polarization curve. This is due to the ohmic and the concentration overpotentials. With the open type cell, the slope increases with decreasing GDL thickness, while the slope of the curve of the channel type cell is independent of the GDL thickness. The voltage of the channel type cell is higher than that of the open type cell at the same GDL thickness in the middle range of current density, Fig. 2. These results of the cell voltage for the GDL thickness in the middle range are opposite trend for the effects of the concentration overpotentials, and are considered to be caused mainly by the difference in the ohmic overpotentil.

To investigate the influence of the ohmic overpotential in detail, the cell impedance was measured. The measurement values of cell impedance at a $1 \mathrm{~A}\left(60 \mathrm{~mA} \mathrm{~cm}^{-2}\right)$ constant load are summarized in Table 1 . The cell impedances measured at a frequency of $1 \mathrm{kHz}$ indicate the sums of the electric and protonic resistance of separator, GDL, membrane electrode assembly (MEA) and other components. As shown in Table 1, the open type cell impedance decreases with increasing GDL layer thickness. In the channel type cell, the cell impedance is somewhat high with a GDL thickness of $0.1 \mathrm{~mm}$, but the differences in the impedances for the various GDL thicknesses is negligible. The cell impedances of the channel type are also significantly lower than that of the open type. These results are in good agreement with the tendencies of the polarization curves in the middle range, Fig. 2.

The difference in cell impedance for the GDL thickness is caused by the electric resistance along the layers and the contact resistance between the different parts. The contact resistance decreases as the contact pressure between the separator and the GDL and between the GDL and the MEA decreases. To measure the contact pressure distribution, a pressure sensitive paper was used instead of the MEA for the open and the channel type cells. Fig. 3 shows photographs of the pressure sensitive papers after assembly, here the highly-colored region (dark in the figure) corresponds to the pressurized area. The channel type separator with $6 \mathrm{~mm}$ deep and $2 \mathrm{~mm}$ wide channels was used. The pressure distribution of the channel type cell was uniform over all of the pressure sensitive paper. However, a slightly pressurized area appears in the center of the pressure sensitive papers of the open type cell. This is due to poor separator plate rigidity because the highly rigid end-plate can directly pressurize only the edge of the MEA plane in the open type cell. An increase in the GDL rigidity also explains that the pressurized region spreads slightly in the open type cell with the GDL of $0.54 \mathrm{~mm}$. On the other hand, both the separator and the end-plate of the channel type cell tightens up all of the MEA plane because no opening slits for ambient air supply are necessary, and this realizes a sufficiently strong and uniform contact pressure distribution across the cell layers 
even when the GDL is thin. The tendency of the measured surface pressure distribution corresponds to that of the cell impedance in Table 1 and the contact resistance is considered to be the dominant factor affecting the cell impedance.

The results in this section allow the conclusion that the channel type cell is advantageous in contact resistance and that it is comparable to the open type cell in the performance of the oxygen supply in this study using a free-breathing PEMFC with an active area of $18 \mathrm{~cm}^{2}$. It also shows that a thicker GDL improves the contact resistance but blocks the oxygen supply significantly, and especially for the channel type, a GDL of about 0.54 $\mathrm{mm}$ thickness is optimum because further increases in GDL thickness do not improve the cell impedance. It is concluded that a cathode structure that gives rise to a uniform pressure distribution over all of the cell layers is valuable to improve the cell performance and that the channel type separator is more suitable than the open type separator for a free-breathing PEMFC. In addition, with the open type cell it becomes more difficult to increase the separator rigidity with larger active areas, while the channel type cell can be designed in a multi-layer stack structure.

\subsection{Effect of convection at the cathode side}

The channel type fuel cell maintains a uniform surface pressure and low contact resistance. The natural convection that controls the oxygen supply is influenced by the channel structure, and it may be expected that optimization of the channel shape will result in improvements in cell performance. This section investigates the effects of channel depth and width with the channel type separator on the cell performance.

Polarization curves of channel type cells with various depths and widths of separator channels are shown in Fig. 4. The GDL thickness at the cathode side was $0.54 \mathrm{~mm}$. In the cases with $1 \mathrm{~mm}$ or $2 \mathrm{~mm}$ wide channels, the cell performance becomes better as the channel depth increases. An increase to $10 \mathrm{~mm}$ in depth of the $2 \mathrm{~mm}$ wide channel drastically enhances the limiting current density, where voltage drops abruptly, while increases in depth with the $1 \mathrm{~mm}$ wide channel is less effective. These results demonstrate that the cell performance is strongly affected by the cross sectional shape of the channel which restricts the natural convection.

Fig. 5 shows the peak power densities obtained from the polarization curves in Fig. 4., where the abscissa is the channel depth. As the channel depth and width increases, the peak power density increases. The gradient of the peak power density curve of the $2 \mathrm{~mm}$ wide channel decreases gradually with increasing channel depth and the improvement above $10 \mathrm{~mm}$ channel depths may be expected to be smaller. The peak power density of the $1 \mathrm{~mm}$ wide channel rises linearly until the channel depth reaches $10 \mathrm{~mm}$, but the power densities are smaller than those of the $2 \mathrm{~mm}$ wide channel. It is difficult to increase the depth of $1 \mathrm{~mm}$ wide channels above $10 \mathrm{~mm}$ because of processing problems, and also wider channel widths than $2 \mathrm{~mm}$ are expected to deteriorate the uniformity of the surface pressure distribution and the electric resistance. Therefore, it may be concluded here that the optimum channel shape is $2 \mathrm{~mm}$ wide and $10 \mathrm{~mm}$ deep, and the maximum peak power density was $105 \mathrm{~mW} \mathrm{~cm}$ in the experiments.

The effect of the orientation of the cell on the performance is examined in Fig. 6, where the orientation is that of the channel or slit, the vertical orientation as shown in Fig. 1 was used for all the previous measurement. The optimum channel shape of $2 \mathrm{~mm}$ width and $10 \mathrm{~mm}$ depth was used for the channel type cell and the $1 \mathrm{~mm}$ wide opening silt separator was used for the open type separator. The GDL of the cathode side was $0.54 \mathrm{~mm}$. In the channel type cell, the voltage in the horizontal orientation rapidly decreases at current densities higher than 100 $\mathrm{mA} \mathrm{cm}{ }^{-2}$. This result supports the suggestion that the natural convection affecting the oxygen supply plays an important role in the cell performance of the channel type cell. There are no significant differences between the performances with the horizontal and vertical orientations for the open type cell. This may be explained as it is not 
oxygen supplied by natural convection that dominates the performance of open type cells, but rather the high electric resistance caused by high contact resistance, as mentioned previously.

Air supply with natural convection was investigated above. It is however possible that forced airflows would affect the cell performance and this was investigated with a small-scale fan. Fig. 7 shows the cell performance of the channel and open type cells with the air supply to the cathode side provided by a small-scale fan. The channel width of the channel type separator was $2 \mathrm{~mm}$. The air was supplied from the bottom open ends of cathode separator, where the measured airflow velocities above the channel outlet were about $4.5 \mathrm{~m} \mathrm{~s}^{-1}$ for the $10 \mathrm{~mm}$ deep cannel and about $1.7 \mathrm{~m} \mathrm{~s}^{-1}$ for the $2 \mathrm{~mm}$ deep channel. The performance of the channel type cell is significantly improved with the small-scale fan. The cell performance of the cell with the $2 \mathrm{~mm}$ channels with fan becomes equal to that of a cell with $10 \mathrm{~mm}$ deep channels. The performance of the open type cell is independent of the airflow provided by the fan because of the dominant high contact resistance. These results show that the channel type cell is superior to the open type cell particularly when installation of a small-scale fan is possible.

\subsection{Numerical analysis of the increase in concentration overpotential}

The experiments in section 3.2 showed that the channel shape strongly influences the performance of the channel type cell. To understand the factors dominating the oxygen supply to the cathode reaction layer, a three-dimensional numerical analysis was conducted on the natural convection inside the cathode channel and the distribution of oxygen and water vapor concentration in this part of the cathode. The PEM module of FLUENT was used for the numerical analysis [9-13]. This module simulates the electrochemical reaction in the MEA, the current distribution in the GDL and the separator, the gas flow and gas concentration distribution in the GDL and the channel, and the temperature distribution in all the domains of the cell. The steady state analysis was performed using a single-phase model which treated the generated water as vapor. The convection in the cathode, which is an important factor in the free-breathing PEMFC, is generated by two factors arising from the reaction. One is the convection from the catalyst layer toward the channel, caused by the overall produced gas in the catalyst layer where oxygen is consumed and vapor is produced. Another is the vertically upward convection by buoyancy due to the density change of gas. We confirmed that this module can consider both of these factors and it can evaluate the effect of convection.

A diagram of the simulation model for a free breathing PEMFC is shown in Fig. 8. The cell design parameters and the calculated conditions are summarized in Tables 2, 3 and 4. The values in Table 2 and 4 are identical with the experimental conditions, while the default values in Ref. (9) were used for the other cell component properties in Table 3 because of the lack of accurate data. The simulation region was in the model shown in Fig. 8 and the boundary conditions of the inlet and outlet of the cathode channels were given by the condition that air at atmospheric pressure and room temperature, $20^{\circ} \mathrm{C}$, could flow in and out freely. A constant temperature condition at room temperature, $20{ }^{\circ} \mathrm{C}$, was also given to the side walls of the separator as shown in Fig. 8, because the changes in the measured temperature of the outer walls of both anode and cathode separators were negligible during the experiments.

To investigate the phenomenon of the poor oxygen supply at the cathode side, Fig. 9 shows the distributions of oxygen mole fractions under the condition that the cell voltage decreased rapidly in the simulations. The cell voltage and current density conditions are $0.4 \mathrm{~V}, 170 \mathrm{~mA} \mathrm{~cm}^{-2}$ for the $2 \mathrm{~mm}$ deep channel and $0.3 \mathrm{~V}, 329 \mathrm{~mA} \mathrm{~cm}^{-2}$ for the $10 \mathrm{~mm}$ deep channel, and the distributions are on the $x-y$ plane at $z=2 \mathrm{~mm}$ (center of the channel) in the channel. In the $2 \mathrm{~mm}$ deep channel, oxygen is almost completely exhausted in the upper part of the downstream region, however, enough oxygen remains even near the channel exit $(y=40 \mathrm{~mm})$ in the $10 \mathrm{~mm}$ deep channel. Fig. 10 shows the temperature distribution on the same plane as in Fig. 9 in the $10 \mathrm{~mm}$ deep channel. The temperature 
of GDL surface increases and remains about $24^{\circ} \mathrm{C}$, and the average density change of gas in the channel due to temperature rise is about $0.006 \mathrm{~kg} \mathrm{~m}^{-3}$. On the other hand, the average density change of gas in the channel due to gas composition change is about $0.050 \mathrm{~kg} \mathrm{~m}^{-3}$. This indicates that the natural convection is mainly caused by the change in gas composition due to the reaction.

Fig. 11 shows the velocity profiles of the gas near the exit of the channel in Fig. $9(y=40 \mathrm{~mm})$. The natural convection in the cathode channel is considered to be determined both by the buoyancy, which was generated by the temperature increase and change in gas composition, and by the channel resistance. Although the maximum flow velocity in the $10 \mathrm{~mm}$ deep channel is slightly higher than that in the $2 \mathrm{~mm}$ channel, the velocity distribution profiles in the velocity boundary layer are very similar. The flow rates of the gas are $1.15 \times 10^{-7} \mathrm{~kg} \mathrm{~s}^{-1}$ in the $2 \mathrm{~mm}$ deep channel and $5.78 \times 10^{-7} \mathrm{~kg} \mathrm{~s}^{-1}$ in the $10 \mathrm{~mm}$ deep channel, so the gas availability for the cell with $10 \mathrm{~mm}$ deep channels is about the one fifth of the cell with $2 \mathrm{~mm}$ channels. The supply rate of oxygen to the GDL surface is mainly determined by the velocity distribution profile in the velocity boundary layer and the difference in the oxygen concentration between on the GDL surface and in the main stream of gas. Therefore, the performance difference is mainly due to the difference in the oxygen concentration in the downstream region, and the concentration depends on the flow rate of the gas.

To examine the concentration profile on the cathode electrode plane in detail, the distributions of oxygen concentrations in the cathode GDL and the channels are shown in Fig. 12. The profiles are along the lines $z=2$ $\mathrm{mm}$ (center of the channel) and $\mathrm{y}=5 \mathrm{~mm}$ (near the inlet), $22.5 \mathrm{~mm}$ (center), and $40 \mathrm{~mm}$ (near the outlet). It shows that the molar fraction of oxygen becomes less than 0.03 on the MEA surface in the downstream region even with $10 \mathrm{~mm}$ deep channel. The oxygen concentration decreases in the $2 \mathrm{~mm}$ deep channel, while the concentration in the main stream of the gas remains adequate but the large gradient in oxygen concentration in the GDL induces the high oxygen supply rate in the $10 \mathrm{~mm}$ deep channel. The current density in the $10 \mathrm{~mm}$ deep channel is about twice that of the $2 \mathrm{~mm}$ deep channel. From this result, it can be concluded that the increases in concentration overpotential are mainly caused by a shortage of oxygen in the $2 \mathrm{~mm}$ deep channel and by the high oxygen transfer rate in and near the GDL in the $10 \mathrm{~mm}$ deep channel, respectively. The experimental result shows that the improvement is reduced in the $2 \mathrm{~mm}$ wide channel with a depth of more than $10 \mathrm{~mm}$, as shown in Fig. 5 . It can be explained by the cell performance being controlled not by a shortage of oxygen in the main stream but by the oxygen transfer rate toward the GDL surface, which is a function of boundary layer thickness, in the channel with a depth of more than $10 \mathrm{~mm}$.

Fig. 13 shows the mole fraction of water vapor on the same line as in Fig. 12. In spite of the lower current density, the mole fractions of water vapor in the $2 \mathrm{~mm}$ deep channel are higher than those in $10 \mathrm{~mm}$ deep channel. The lower flow rate of the $2 \mathrm{~mm}$ deep channel increases the rate of generated water vapor and consumed oxygen to the flow rate, which causes a higher mole fraction of water vapor and a lower mole fraction of oxygen.

\section{Conclusions}

The effect of the cathode separator structure on the performance characteristics of a free-breathing PEMFC was studied by experiments and numerical analysis. The results may be summarized as follows:

1. In cells with open type cathode separators, the contact resistance of the cell becomes high because it is difficult to realize a sufficiently strong and uniform contact pressure distribution across the cell layers. The high contact resistance has a stronger influence on the cell performance than the characteristics of the natural convection. 
2. The channel type cathode separator can maintain low contact resistance and the cell performance is controlled by the supply of oxygen by natural convection in the channels. The supply of oxygen is strongly affected by the cross-sectional shape of the cathode separator channel, and the maximum peak power density of the cell with the $18 \mathrm{~cm}^{2}$ active area investigated here is $105 \mathrm{~mW} \mathrm{~cm}^{-2}$ using $10 \mathrm{~mm}$ deep and $2 \mathrm{~mm}$ wide channels.

3. The numerical analysis demonstrated that the natural convection is mainly caused not by temperature rise but by the change in gas composition due to the reaction in the cell with channel type separators. The maximum current density limitations on the cathode channel type cell arise due to the concentration overpotential on the cathode side. The limitations of the cell with $2 \mathrm{~mm}$ wide and $2 \mathrm{~mm}$ deep channels are due to oxygen shortage in the channel downstream part. On the other hand, with $2 \mathrm{~mm}$ wide and $10 \mathrm{~mm}$ deep channels, the oxygen concentration in the main stream is adequate and the mass transfer rate of oxygen toward the surface of gas diffusion layer, which is a strong function of natural convection in the cathode channel, is predominant.

\section{Acknowledgment}

The authors thank K. Tanemura (an undergraduate student of Hokkaido University) for assistance with the experimental studies.

\section{References}

[1] C.K. Dyer, J. Power Sources 106 (2002) 31-34.

[2] A. Heinzel, C. Hebling, M. Muller, M. Zedda, C. Muller, J. Power Sources 105 (2002) 250-255.

[3] A. Schmitz, M. Tranitz, S. Wagner, R. Hahn, C. Hebling, J. Power Sources 118 (2003) 162-171.

[4] T. Hottinen, M. Mikkola, P. Lund, J. Power Sources 129 (2004) 68-72.

[5] T. Hottinen, O. Himanen, P. Lund, J. Power Sources 138 (2004) 205-210.

[6] T. Hottinen, M. Noponen, T. Mennola, O. Himanen, M. Mikkola, P. Lund, J. Appl. Electrochem. 33 (2003) 265-271.

[7] S. Morner, A. Klein, J. Sol. Energy Eng. 123 (2001) 225-231.

[8] M. Noponen, T. Mennola, M. Mikkola, T. Hottinen, P. Lund, J. Power Sources 106 (2002) 304-312.

[9] Fluent 6.2 User's Guide, Fluent Inc, Lebanon, NH (2005).

[10] T. Springer, T. Zawodzinski, S. Gottesfeld, J. Electrochem. Soc. 138 (1991) 2334-2342.

[11] T. Springer, M. Wilson, S. Gottesfeld, J. Electrochem. Soc. 138 (1993) 3513-3526.

[12] S. Um, C.Y. Wang, J. Power Sources 125 (2004) 40-51.

[13] H. Meng, C.Y. Wang, J. Electrochem. Soc. 151 (2004) 358-367. 

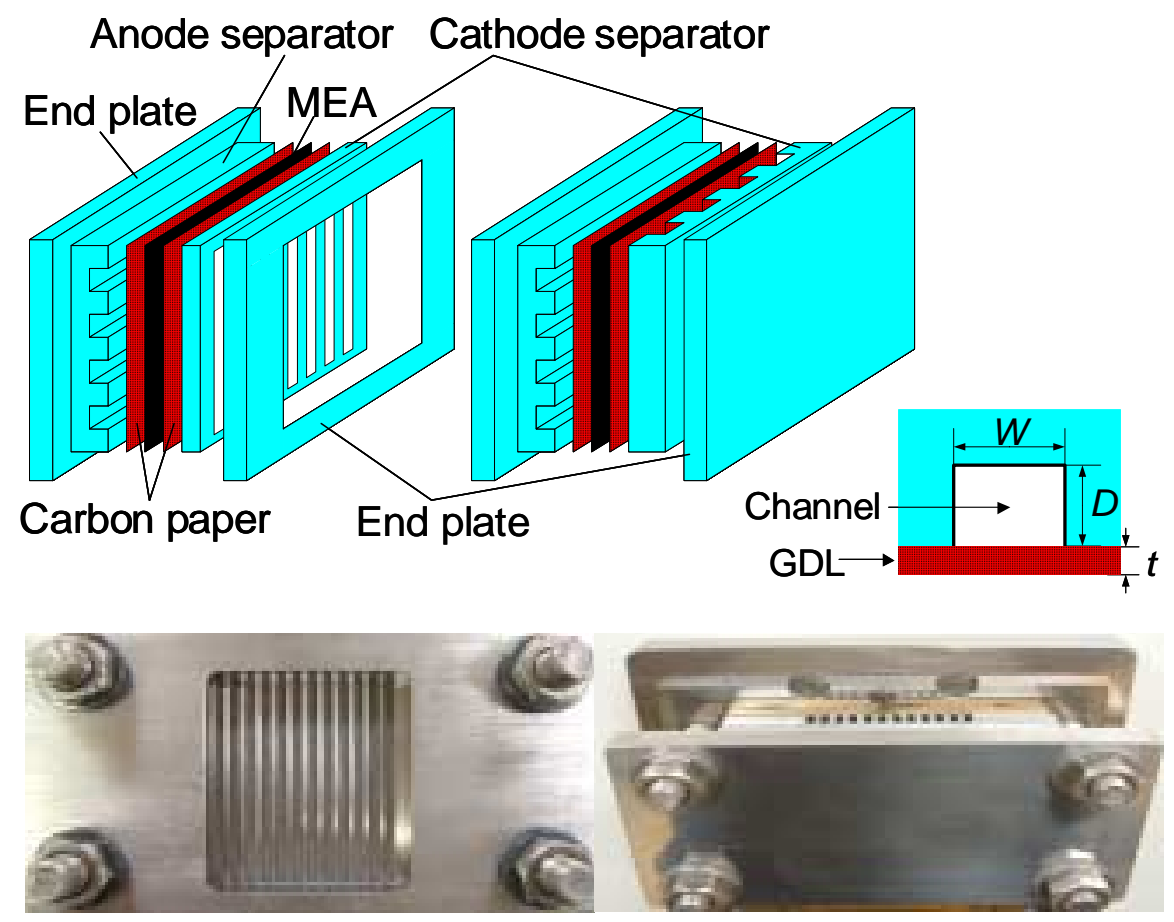
(a) Open type
(b) Channel type

Fig. 1. Schematic illustration and views of free-breathing PEMFCs. 


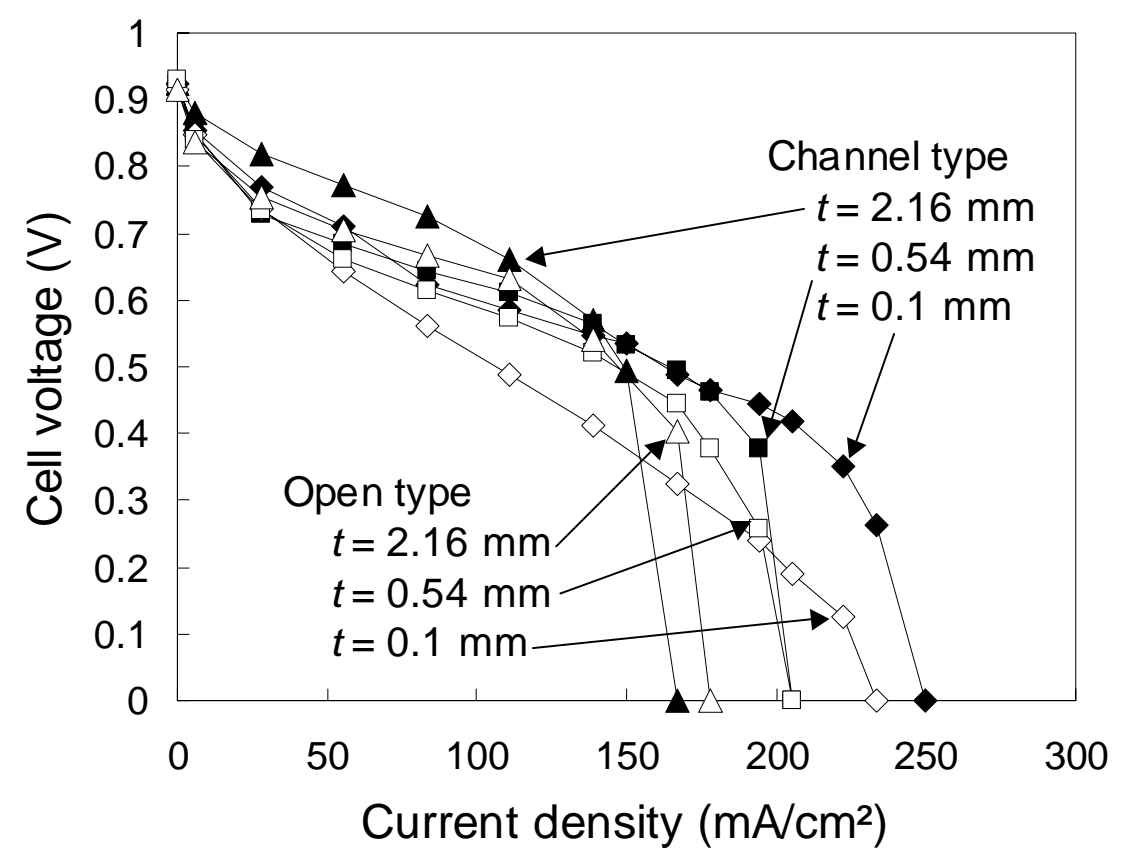

Fig. 2. Polarization curves of the open and channel type cathode equipped cells with various diffusion layer thicknesses, $t$. 

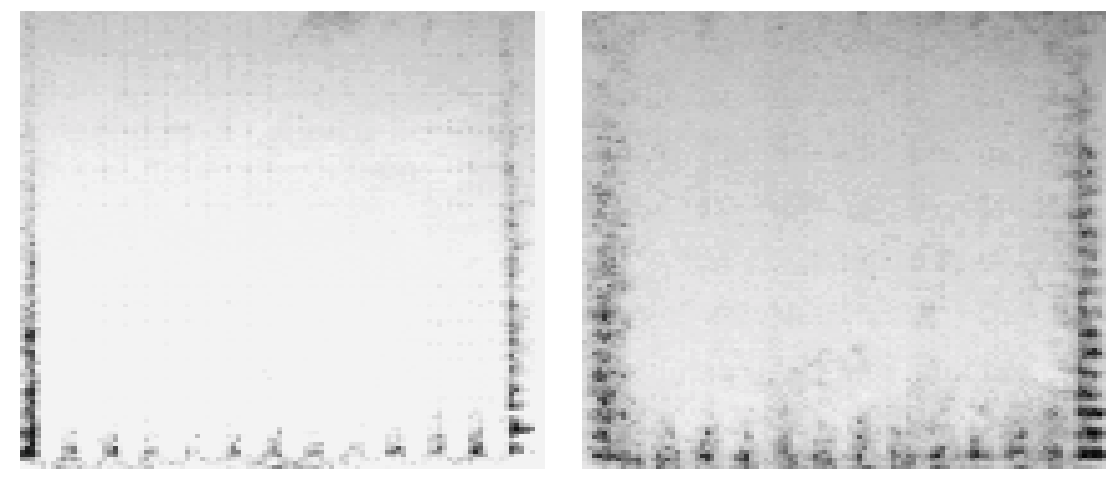

$$
t=0.1 \mathrm{~mm} \quad \text { (a) Open type } \quad t=0.54 \mathrm{~mm}
$$

(a) Open type

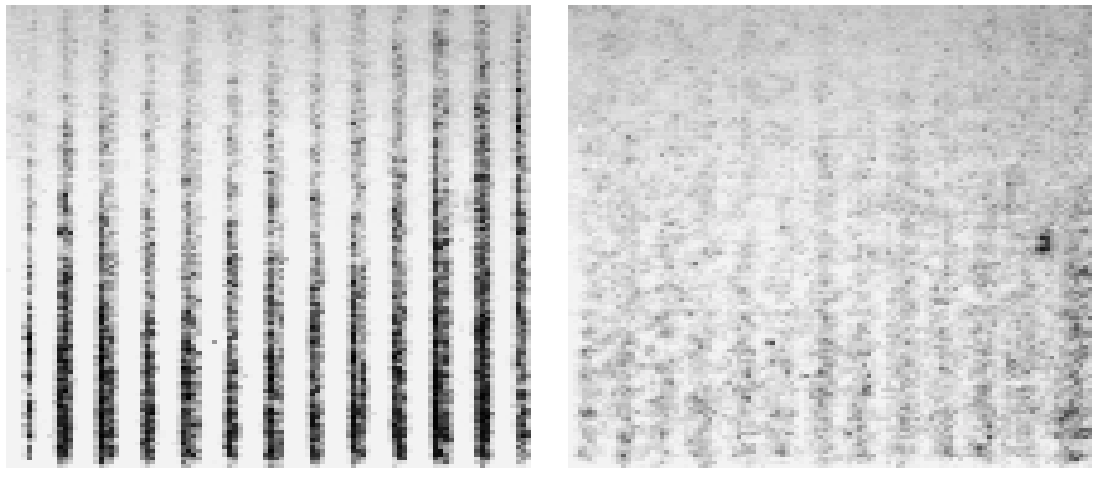

$$
t=0.1 \mathrm{~mm}
$$

(b) Channel type

$t=0.54 \mathrm{~mm}$ m. 3. Contact pressure distribution of open and channel type cathodes 


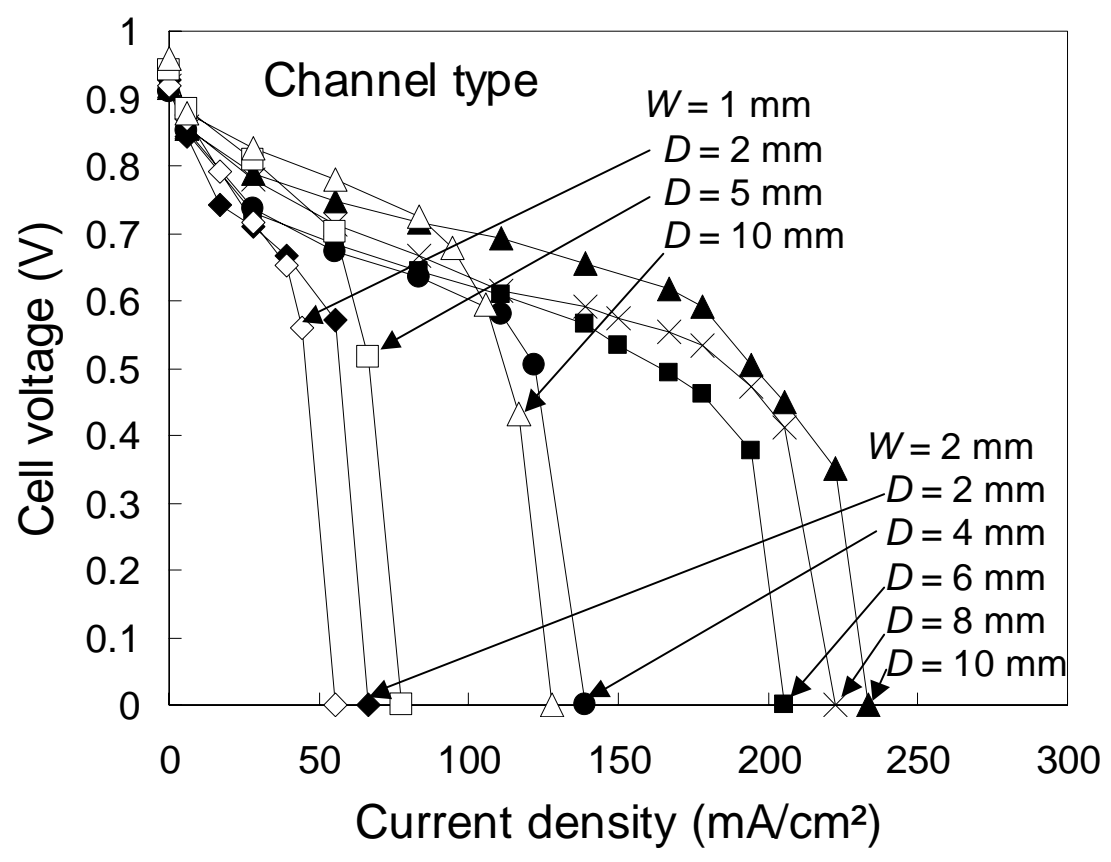

Fig. 4. Polarization curves with the channel type cathode with various depths and widths of the channels: gas diffusion layer thickness $0.54 \mathrm{~mm}$. 


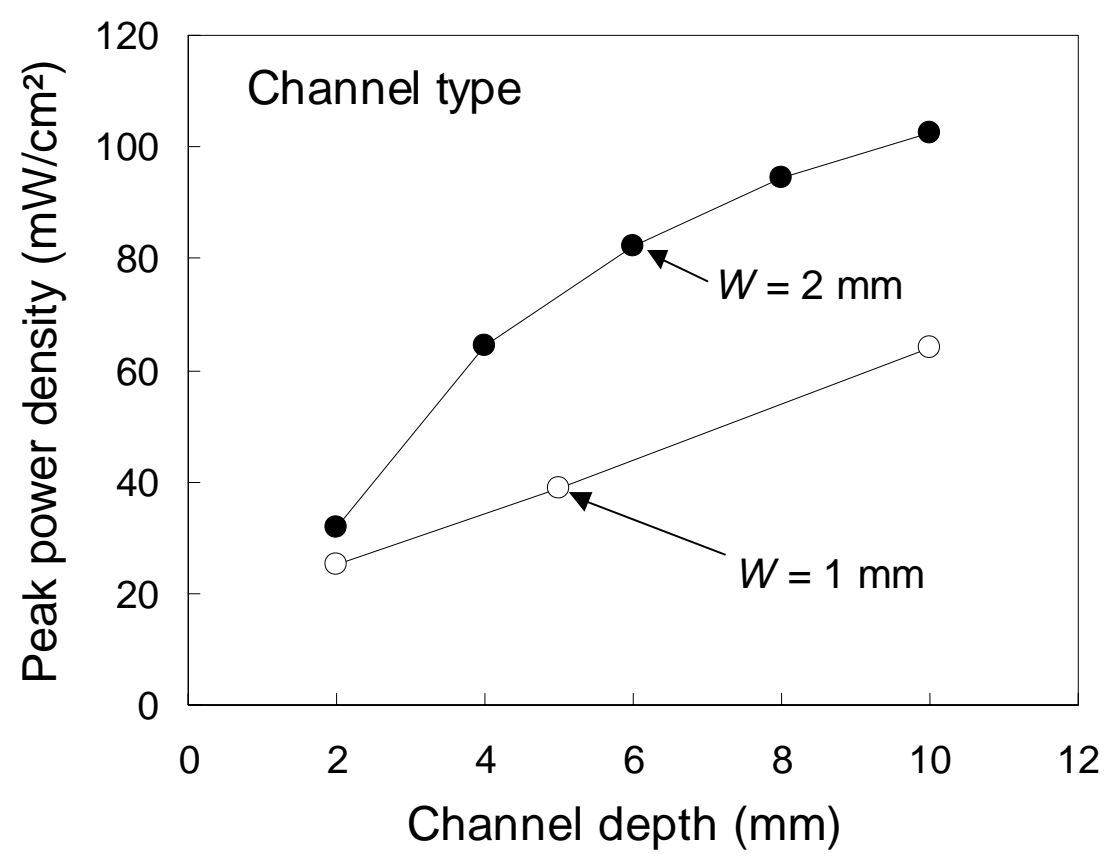

Fig. 5. Peak power densities derived from the polarization curves in Fig. 4. 


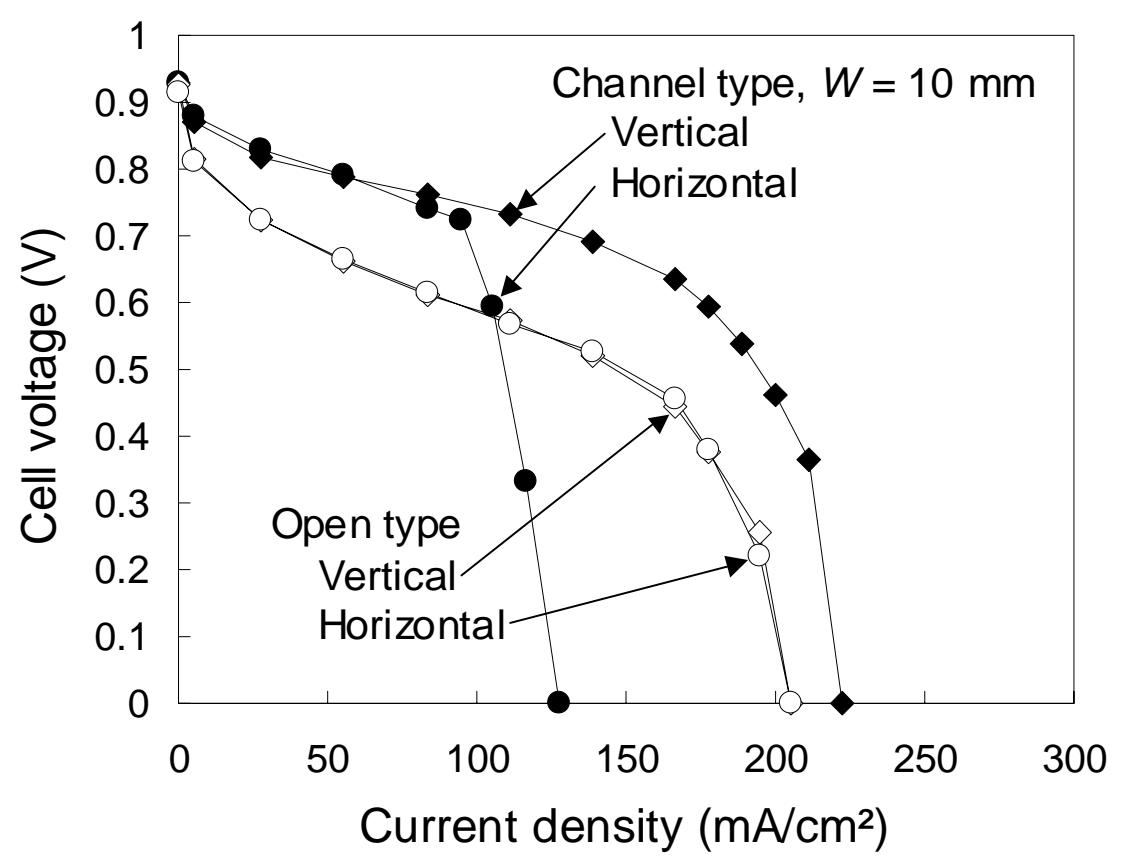

Fig. 6. Polarization curves of open and channel type cathodes oriented horizontally and vertically: gas diffusion layer thickness $0.54 \mathrm{~mm}$. 


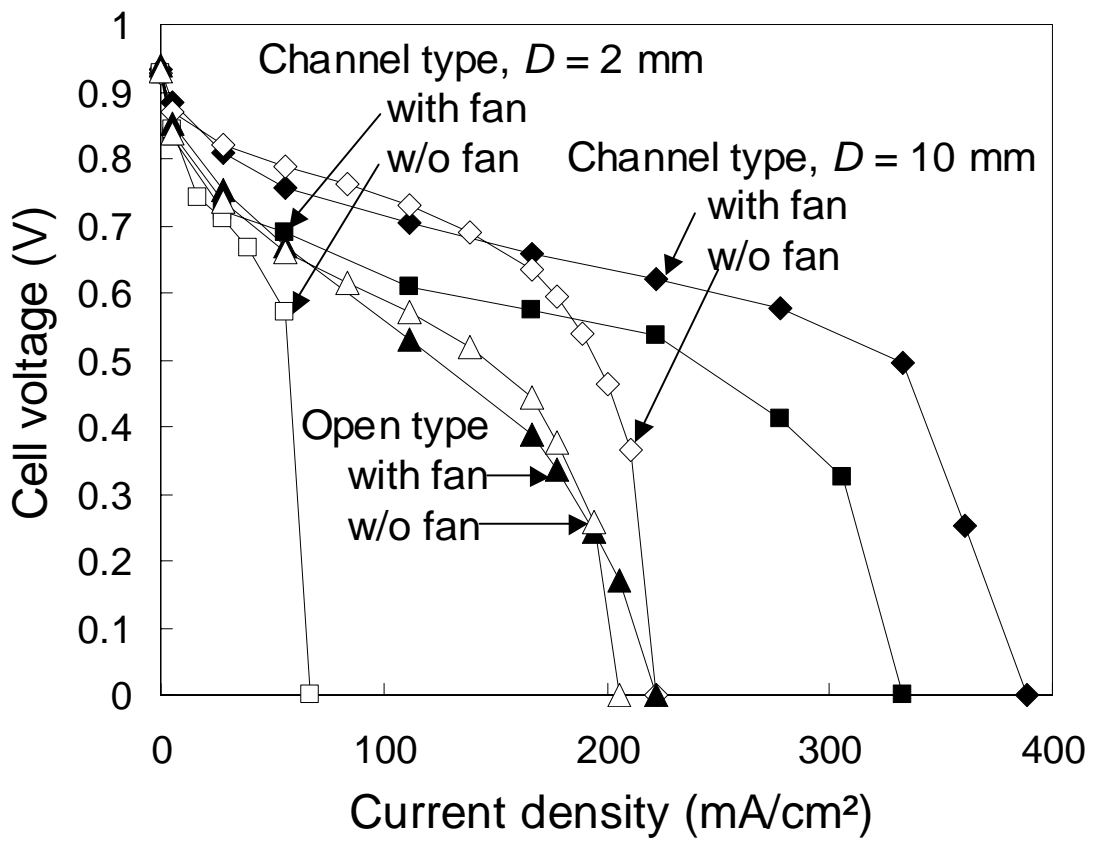

Fig. 7. Polarization curves of open and channel type cathodes when supplying air to the cathode side with and without a fan: gas diffusion layer thickness $0.54 \mathrm{~mm}$. 


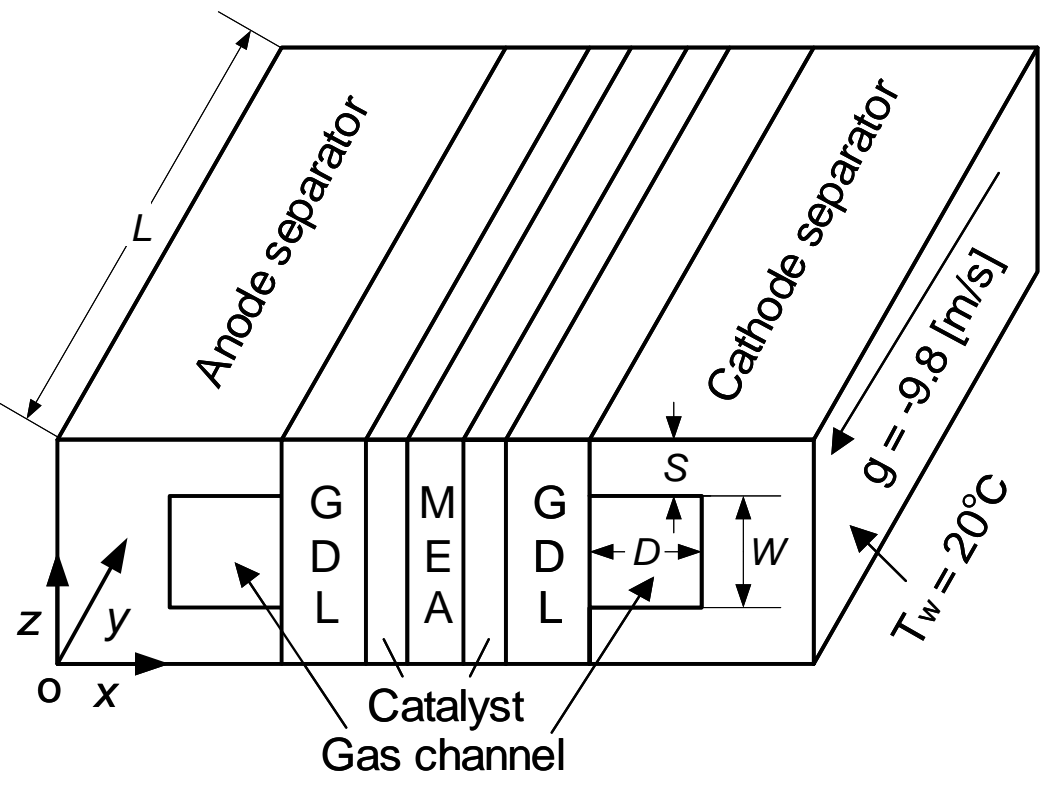

Fig. 8. Three-dimensional schematic diagram and geometrical outline of the simulation model. 


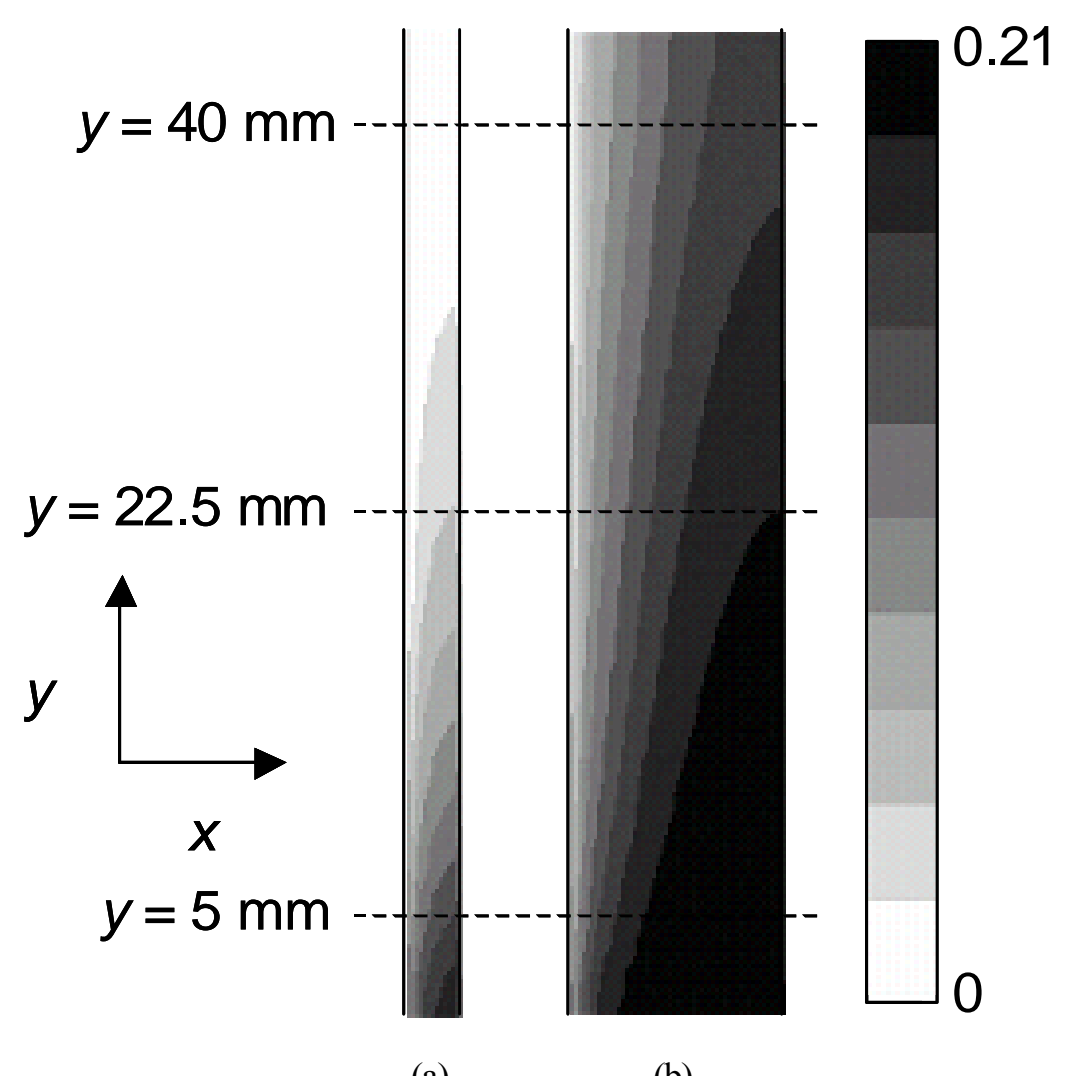

(a)

(b)

Fig. 9. Oxygen mole fraction contours in the $x-y$ plane at $z=2 \mathrm{~mm}$ (center of the channel), (a) channel depth $2 \mathrm{~mm}$ at $0.4 \mathrm{~V}, 170 \mathrm{~mA} \mathrm{~cm}^{-2}$ and (b) channel depth $10 \mathrm{~mm}$ at $0.3 \mathrm{~V}, 329 \mathrm{~mA} \mathrm{~cm}^{-2}$. 


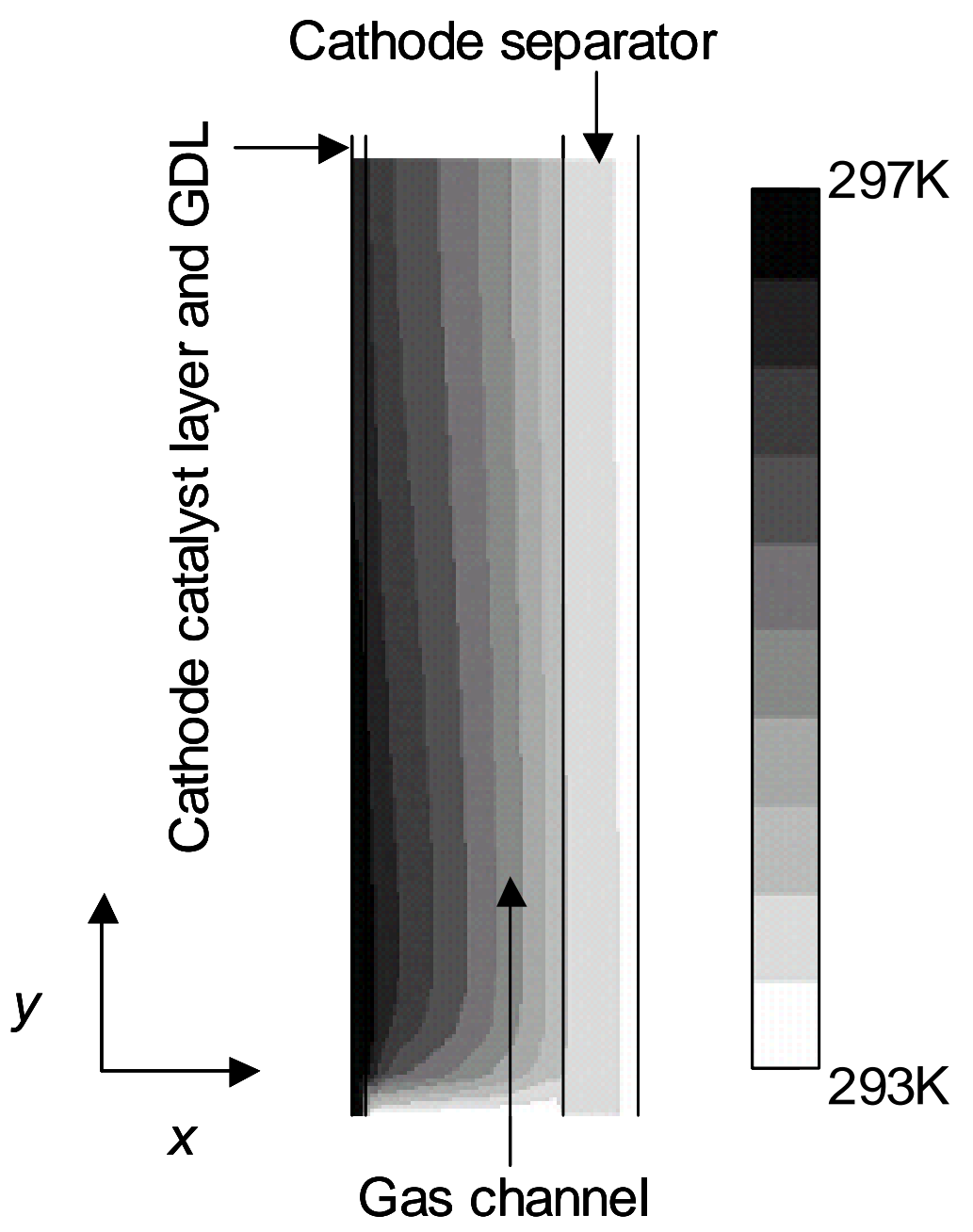

Fig. 10. Temperature contours in the $x-y$ plane at $z=2 \mathrm{~mm}$ (center of the channel), channel depth $10 \mathrm{~mm}$ at $0.3 \mathrm{~V}, 329 \mathrm{~mA} \mathrm{~cm}^{-2}$. 


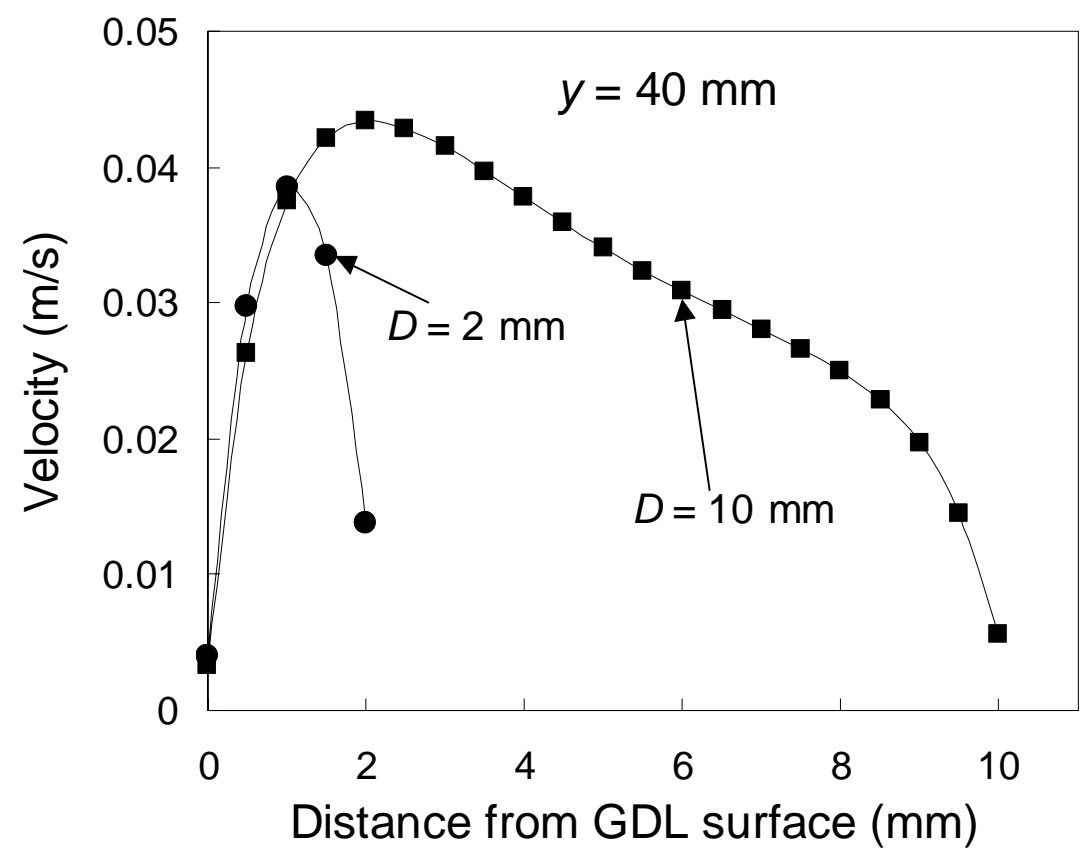

Fig. 11. Velocity profiles in the cathode gas channel along the $x$-direction at $y=40 \mathrm{~mm}$ (exit of the channel) and $z=2 \mathrm{~mm}$ (center of the channel). 


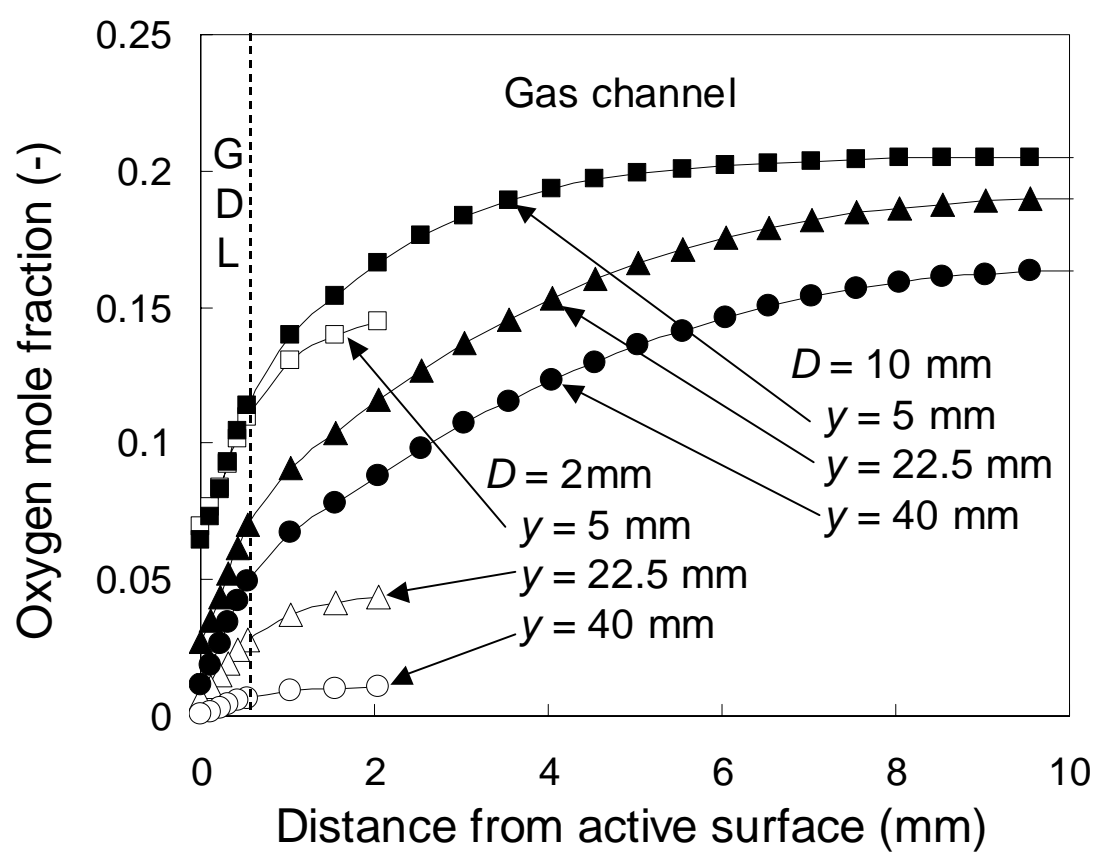

Fig. 12. Local profiles of the oxygen mole fraction along the $\mathrm{x}$-direction at $z=2$ $\mathrm{mm}$, channel depth $2 \mathrm{~mm}$ at $0.4 \mathrm{~V}, 170 \mathrm{~mA} \mathrm{~cm}^{-2}$ and $10 \mathrm{~mm}$ at $0.3 \mathrm{~V}, 329 \mathrm{~mA} \mathrm{~cm}^{-2}$. 


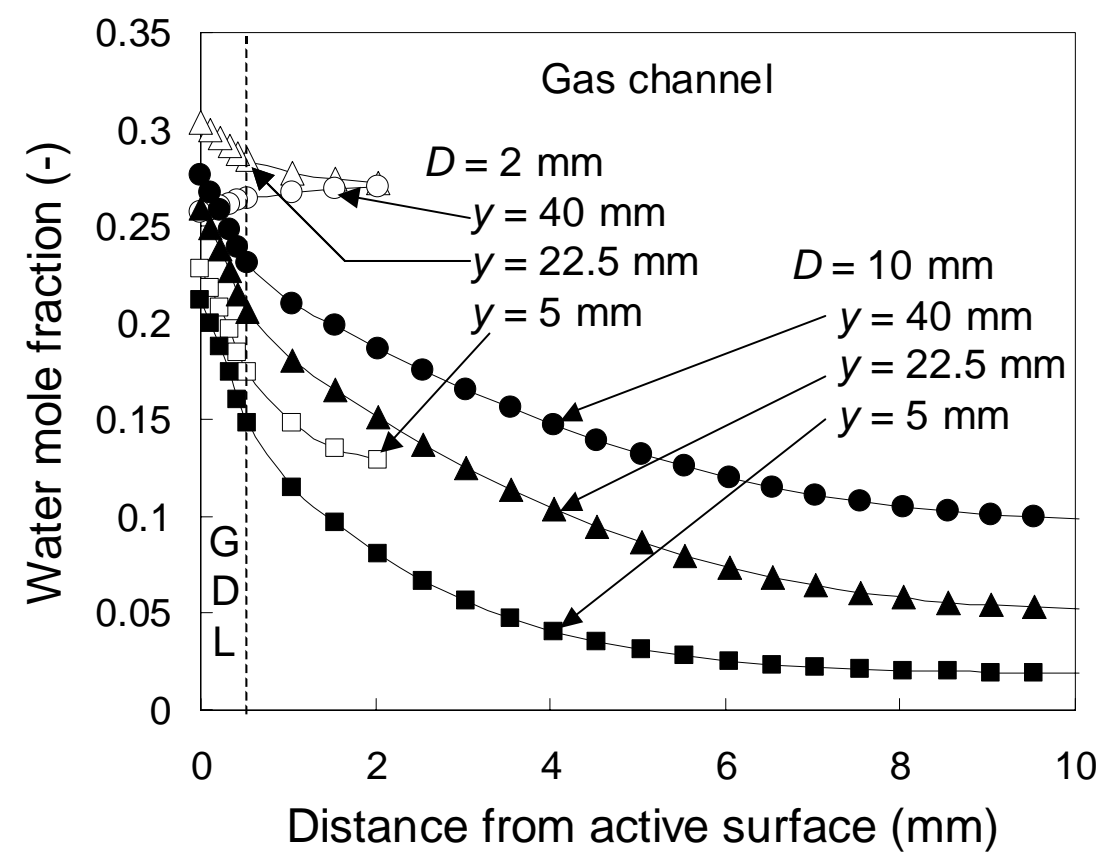

Fig. 13. Local profiles of the water vapor mole fraction along the $x$-direction at $z=2 \mathrm{~mm}$, channel depth $2 \mathrm{~mm}$ at $0.4 \mathrm{~V}, 170 \mathrm{~mA} \mathrm{~cm}^{-2}$ and $10 \mathrm{~mm}$ at $0.3 \mathrm{~V}, 329$ $\mathrm{mA} \mathrm{cm}{ }^{-2}$. Fig. 12. Local profiles of the water vapor mole fraction along the $x$-direction at $z=2 \mathrm{~mm}$, channel depth $2 \mathrm{~mm}$ at $0.4 \mathrm{~V}, 170 \mathrm{~mA} \mathrm{~cm}^{-2}$ and $10 \mathrm{~mm}$ at $0.3 \mathrm{~V}, 329 \mathrm{~mA} \mathrm{~cm}^{-2}$. 
Table 1 Cell impedance at a constant load of $1 \mathrm{~A}\left(60 \mathrm{~mA} \mathrm{~cm}^{-2}\right)$.

\begin{tabular}{|c|c|c|c|}
\hline $\begin{array}{c}\text { Diffusion layer } \\
\text { thickness }\end{array}$ & $0.1 \mathrm{~mm}$ & $0.54 \mathrm{~mm}$ & $2.16 \mathrm{~mm}$ \\
\hline Open type & $43.4 \mathrm{~m} \Omega$ & $28.6 \mathrm{~m} \Omega$ & $21.8 \mathrm{~m} \Omega$ \\
\hline Channel type & $16.2 \mathrm{~m} \Omega$ & $12.7 \mathrm{~m} \Omega$ & $13.4 \mathrm{~m} \Omega$ \\
\hline
\end{tabular}


Table 2 Cell design parameters.

\begin{tabular}{|lc|c|}
\hline \multicolumn{2}{|c|}{ Description } & Value \\
\hline Cell length $(L)$ & {$[\mathrm{mm}]$} & 45 \\
\hline Gas channel depth $(D)$ & {$[\mathrm{mm}]$} & 2,10 \\
\hline Gas channel width $(W)$ & {$[\mathrm{mm}]$} & 2 \\
\hline Current collector width $(S)$ & {$[\mathrm{mm}]$} & 1 \\
\hline Anode GDL thickness & {$[\mathrm{mm}]$} & 0.54 \\
\hline Cathode GDL thickness & {$[\mathrm{mm}]$} & 0.54 \\
\hline Anode catalyst layer thickness & {$[\mathrm{mm}]$} & 0.01 \\
\hline Cathode catalyst layer thickness & {$[\mathrm{mm}]$} & 0.01 \\
\hline Membrane thickness & {$[\mathrm{mm}]$} & 0.02 \\
\hline Porosity of anode GDL & {$[-]$} & 0.78 \\
\hline Porosity of cathode GDL & {$[-]$} & 0.78 \\
\hline GDL electrical conductivity & {$\left[\Omega^{-1} \mathrm{~m}^{-1}\right]$} & 1250 \\
\hline
\end{tabular}


Table 3 Properties of cell components with default values as shown in Ref. (9).

\begin{tabular}{|lc|c|}
\hline \multicolumn{2}{|c|}{ Description } & \multicolumn{1}{c|}{ Value } \\
\hline GDL viscous resistance & {$\left[\mathrm{m}^{-2}\right]$} & $1.0 \times 10^{12}$ \\
\hline Catalyst layer porosity & {$[-]$} & 0.4 \\
\hline $\begin{array}{l}\text { Catalyst layer surface to } \\
\text { volume ratio }\end{array}$ & {$\left[\mathrm{m}^{-1}\right]$} & $1.0 \times 10^{5}$ \\
\hline Catalyst layer viscous resistance & {$\left[\mathrm{m}^{-2}\right]$} & $1.0 \times 10^{12}$ \\
\hline Catalyst layer electrical conductivity & {$\left[\Omega^{-1} \mathrm{~m}^{-1}\right]$} & 1500 \\
\hline Membrane equivalent weight & {$\left[\mathrm{kg} \mathrm{kmol}^{-1}\right]$} & 1100 \\
\hline $\begin{array}{l}\text { Membrane protonic conduction } \\
\text { coefficient }\end{array}$ & {$[-]$} & 0.42 \\
\hline $\begin{array}{l}\text { Membrane protonic conduction } \\
\text { exponent }\end{array}$ & {$[-]$} & 1 \\
\hline
\end{tabular}


Table 4 Calculation conditions.

\begin{tabular}{|lc|c|}
\hline \multicolumn{2}{|c|}{ Description } & Value \\
\hline Room temperature & {$\left[{ }^{\circ} \mathrm{C}\right]$} & 20 \\
\hline Pressure at the anode gas channel inlet & {$[\mathrm{atm}]$} & 1 \\
\hline Relative humidity of hydrogen & {$[\%]$} & 0 \\
\hline Temperature of hydrogen & {$\left[{ }^{\circ} \mathrm{C}\right]$} & 20 \\
\hline Pressure at the cathode gas channel inlet & {$[\mathrm{atm}]$} & 1 \\
\hline Relative humidity of air & {$[\%]$} & 30 \\
\hline Temperature of air & {$\left[{ }^{\circ} \mathrm{C}\right]$} & 20 \\
\hline Hydrogen flow rate for one path & {$\left[\mathrm{kg} \mathrm{s}^{-1}\right]$} & $3.7 \times 10^{-8}$ \\
\hline
\end{tabular}

